\title{
DEVELOPMENT AND VALIDATION OF UV-SPECTROPHOTOMETRIC METHODS FOR DETERMINATION OF GEMCITABINE HYDROCHLORIDE IN BULK AND POLYMERIC NANOPARTICLES
}

\author{
TARANJIT KAUR, SUKHJINDER KAUR, PARMINDERJIT KAUR*
}

Rayat-Bahra Institute of Pharmacy, Bohan, Hoshiarpur

Email: parminderkaur.pk67@gmail.com

Received: 06 May 2017, Revised and Accepted: 22 Aug 2017

\section{ABSTRACT}

Objective: The objective of the present work was to develop and validate a novel, specific, precise and reliable method for estimation of gemcitabine hydrochloride in bulk and polymeric nanoparticles using UV-visible spectroscopy method.

Methods: The UV-Visible spectrophotometric determination was performed with double beam Systronics UV-visible spectrophotometer; model UV-2201 (India). The proposed methods were validated for various parameters like linearity, precision, accuracy, robustness, ruggedness, detection, quantification limits, and formulation analysis as per international conference on harmonization (ICH) guidelines.

Results: The method was based on measurement of absorbance at wavelength maxima i.e. $267.2 \mathrm{~nm}, \lambda_{\max }$ of the drug in distilled water, phosphate buffer $\mathrm{pH} 6.8$ and 7.4. The method obeyed Beer Lambert's law in the concentration range of 5-30 $\mu \mathrm{g} / \mathrm{ml}^{2}$ andR ${ }^{2}-\mathrm{value}$ was found to be 0.999 . Moreover, the \% drug recovered from polymeric nanoparticles was found to be $97.97 \%$.

Conclusion: According to results, the currently developed method shows compliance with acceptance criteria with Q2 (R1) and international conference on harmonization (2005) guidelines, because the \% RSD was found to be less than $2 \%$. The developed method was simple, accurate and précised.

Keywords: Gemcitabine Hydrochloride, UV-Visible Spectrophotometer, Correlation coefficient, $\lambda_{\max }$

(C) 2017 The Authors. Published by Innovare Academic Sciences Pvt Ltd. This is an open access article under the CC BY license (http://creativecommons.org/licenses/by/4.0/) DOI: http://dx.doi.org/10.22159/ijap.2017v9i5.19726

\section{INTRODUCTION}

Method validation is the process which is used to confirm that the analytical procedure employed fora specific test is suitable for its intended use. Results from method validation can be used to judge the quality, reliability and consistency of analytical results as well as it is an integral part of any good analytical practice [1].

Gem $\mathrm{HCl}$ is 2'-Deoxy-2',2'-difluoro cytidines hydrochloride (C9H11F2N304. $\mathrm{HCl}$ ) as shown in fig. 1, deoxycytidine analogue with small molecular weight (299.66), has a short half-life (17 $\mathrm{min})$ appearance (white to off white solid) and quickly decomposed to inactive products after administration [2]. The drug is highly hydrophilic in nature, slightly soluble in methanol and practically insoluble in ethanol and polar organic solvents. The major limitation for the use of gem $\mathrm{HCl}$ is represented by its rapid metabolic inactivation (deamination operated by deoxycytidine deaminase) responsible for its short half-life with its low but still important systemic toxicity [3].

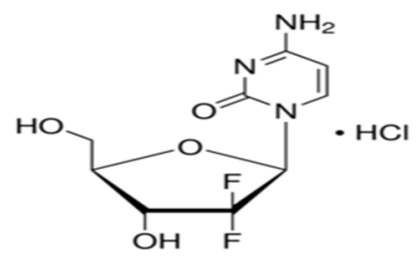

Fig. 1: Structure of gem HCl

Moreover, the gem $\mathrm{HCl}$ is used as an antiviral agent, an enzyme inhibitor, an immunosuppressive agent, radiation-sensitizing agents and also has been successfully used in other tumors such as ovarian cancer, mesothelioma and head and neck cancers in combinations with other cytotoxic drugs [4-5].

By the extensive literature survey, we found that there are numerous methods, such as high-performance liquid chromatography (HPLC) [6-
8], UV-spectrophotometric [9], liquid chromatography with mass detector (LC-MS) [10-11], UPLC-MS/MS [12], have been used to measure the gem $\mathrm{HCl}$ in formulations and biological samples. However, these methods are involved with sophistication, skills, extraction, and more expensive than proposed method.

The reported chromatographic methods were not cost effective due to the use of highly sophisticated detectors and costly solvents. Thus, the present investigation was aimed to develop a rapid, simple, selective, sensitive, precise, accurate, robust, reproducible, and economic and stability indicating spectrophotometric method in bulk as well as in nanoparticles. Moreover, the development of the analytical method is required for analysis of drug in the delivery system as well as for evaluation of in vitro release pattern of the drug from the developed delivery system. The presently developed method was validated as per international conference on harmonization guidelines. The aim of the present study was to develop and validate a new simple, sensitive, rapid, reliable and precise spectrophotometric method for the analysis of gem $\mathrm{HCl}$ in the bulk as well as in polymeric nanoparticles and to check the percent drug recovery from a novel delivery system of drug i.e. nanoparticles.

\section{MATERIALS AND METHODS}

\section{Chemicals and reagents}

Gemcitabine hydrochloride supplied as a gift sample by Neon laboratories, Mumbai. Sodium chloride, potassium dihydrogen orthophosphate, disodium hydrogen phosphate from $\mathrm{CDH}$ laboratories. All chemicals and reagents used in the study were of analytical grade.

\section{Instrumentation}

A double beam systronics UV-visible spectrophotometer, model UV2201 (India) with a spectral bandwidth of $1 \mathrm{~nm}$, wavelength accuracy of $\pm 0.5 \mathrm{~nm}$ and a pair of $1 \mathrm{~cm}$ quartz cells were used to measure the absorbance of the resulting solutions.

Preparation of solvent system for analysis study

For the spectroscopic analysis of drug, three solvents were selected. 


\section{Distilled water}

Phosphate buffer ( $\mathrm{pH}$ 7.4): Dissolve $2.38 \mathrm{~g}$ of disodium hydrogen phosphate, $0.19 \mathrm{~g}$ of potassium dihydrogen phosphate and $8.0 \mathrm{~g}$ of sodium chloride in sufficient water and make up the volume to produce $1000 \mathrm{ml}$. Adjust the $\mathrm{pH}$ if necessary.

Phosphate buffer (pH-6.8): Place $125 \mathrm{ml}$ of $0.2 \mathrm{M}$ potassium dihydrogen phosphate in a volumetric flask, add the $56 \mathrm{ml}$ of $0.2 \mathrm{M}$ sodium hydroxide and then add water to make up the volume.

Preparation of $0.2 \mathrm{M}$ potassium dihydrogen orthophosphate solution: $27.218 \mathrm{~g}$ of potassium dihydrogen phosphate was dissolved in water and make up the volume up to $1000 \mathrm{ml}$.

Preparation of $0.2 \mathrm{M}$ sodium hydroxide: $8 \mathrm{~g}$ of $\mathrm{NaOH}$ was dissolved in water and diluted with water up to $1000 \mathrm{ml}$ [13].

\section{Preparation of standard stock solution and working solution}

The $10 \mathrm{mg}$ of gem $\mathrm{HCl}$ has weighed accurately and transferred into $10 \mathrm{ml}$ volumetric flask and dissolved. Then, the solution was diluted up to the mark with an appropriate solvent (phosphate buffer pH-7.4, $\mathrm{pH} 6.8$ and distilled water). The clear solution was obtained having the strength of $1000 \mu \mathrm{g} / \mathrm{ml}$ (standard stock solution). From this stock solution, $10 \mathrm{ml}$ was taken into a $100 \mathrm{ml}$ volumetric flask, diluted up to $100 \mathrm{ml}$ to get the solution of $100 \mu \mathrm{g} / \mathrm{ml}$ concentration and filtered through Whatman filter paper before analyzing (working solution) [14].

\section{Procedure for calibration curve}

The standard solutions were prepared by the proper dilution of the primary stock solution with phosphate buffer $\mathrm{pH} 7.4, \mathrm{pH} 6.8$ and distilled water to obtain working standard. All the measurements were performed at room temperature. The stock solutions scanned in the UV range $200-800 \mathrm{~nm}$ by using an appropriate blank. For linearity study, dilutions were made for the drug in the range of 1-40 $\mu \mathrm{g} / \mathrm{ml}$ concentrations were prepared by diluting the stock solution with all the three working solvents.

\section{Assay of gem $\mathrm{HCl}$ polymeric nanoparticles}

The proposed method was successfully applied for the determination gem $\mathrm{HCl}$ in polymeric nanoparticles. An accurately measured volume of polymeric nanoparticles equivalent to $10 \mathrm{mg} \mathrm{(7}$ $\mathrm{ml}$ ) of the drug was transferred into $10 \mathrm{ml}$ volumetric flask and volume were made up to the mark with distilled water, filtered through whatmann filter paper. The suitable volume of solution was further diluted with water to obtain concentration $10 \mu \mathrm{g} / \mathrm{ml}$. Then, the aliquot was scanned in the UV range $(200-400 \mathrm{~nm})$. The amount of drug present in the polymeric nanoparticles was calculated [15].

\section{Validation of methods}

Linearity The aliquots of concentration ranging 1-40 $\mu \mathrm{g} / \mathrm{ml}$ were analyzed in triplicate. The results obtained were used to calculate the equation of the line by using linear regression by the leastsquares regression method [16].

Accuracy The accuracy of the method is the closeness of the measured value to the true value for the sample. For recovery study, the solutions were prepared at levels $75 \%, 100 \%$ and $125 \%$ of test solutionand taken absorbance of each solution in triplicate [17].

Precision The intra-day and inter-day precisions of the proposed spectrophotometric methods were determined by estimating the corresponding response thrice on the same day and on three different days, over a period of one week and the results were reported in terms of relative standard deviation [18].

Repeatability The repeatability was determined by analyzing six samples of same concentrations of drug $(20 \mu \mathrm{g} / \mathrm{ml})$. From the resulting absorbance, the standard deviation and relative standard deviation were calculated [19].

\section{Limit of detection (LOD) and limit of quantification (LOQ)}

It is the lowest concentration of analyte in a sample that can be detected but not necessary quantified. The LOD and LOQ were determined by using standard deviation of the response and slope approach as defined in International Conference on Harmonization (ICH) guidelines. LOD and LOQ values were calculated using the relation,

$$
\mathrm{LOD}=3.3 * \sigma / \mathrm{s}
$$

The lowest concentration or amount of analyte that can be determined quantitatively with an acceptable level of repeatability precision

$$
\text { LOQ }=10 * \sigma / s
$$

trueness

Where $\sigma$ is the standard deviation $(n=3)$ of reagent blank determination and $s$ is the slope of the calibration curve [20-21].

\section{Robustness and ruggedness}

The robustness of the proposed method was tested by changing parameters such as wavelength range and slit width. Ruggedness was determined by different analysts, using similar operational and environmental conditionsand the results were reported in terms of $\%$ RSD [22].

\section{RESULTS AND DISCUSSION}

\section{Determination of absorption maxima $\left(\lambda_{\max }\right)$}

The standard stock solution of gem $\mathrm{HCl}$ having the concentration $1000 \mu \mathrm{g} / \mathrm{ml}$ was further diluted to $100 \mu \mathrm{g} / \mathrm{ml}$ with distilled water, $\mathrm{pH}$ 7.4 and 6.8. The absorbance of resulting solution was scanned in the UV spectrophotometer ranging from $200-400 \mathrm{~nm}$. The $\lambda_{\max }$ was found to be $267.2 \mathrm{~nm}$ as shown in fig. 2. The higher values of correlation coefficient $\left(\mathrm{R}^{2}\right)$ indicate good linearity of calibration curve for drug in bulk as well as in formulation.

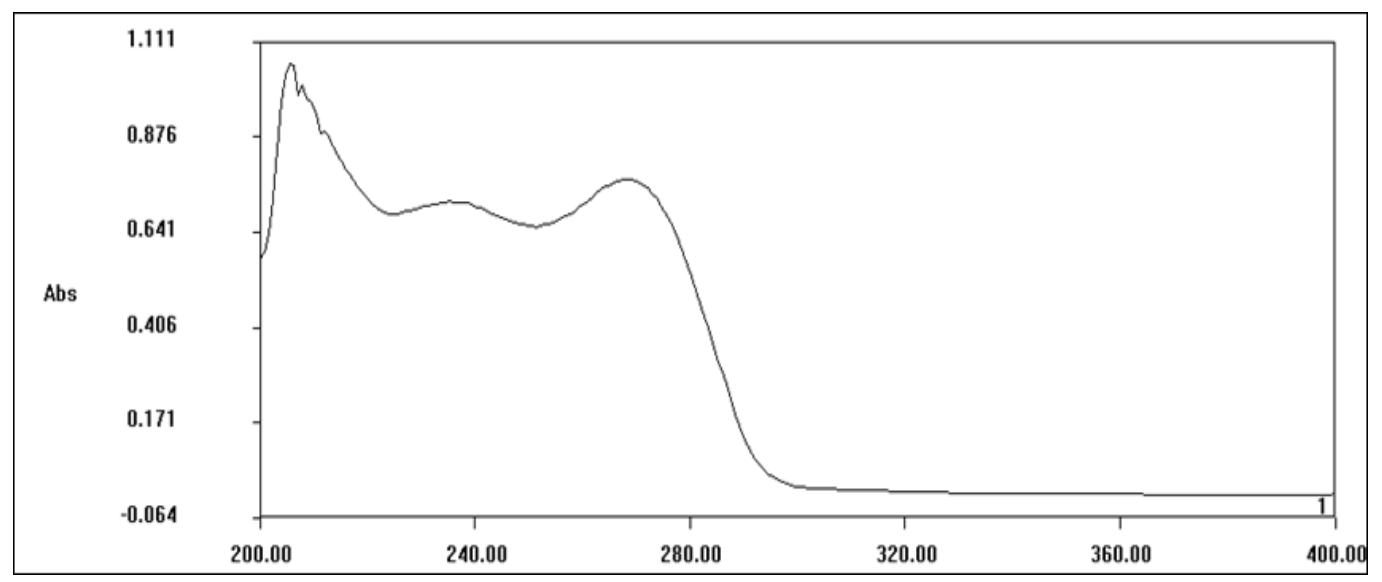

Fig. 2: Absorption spectrum of gem $\mathrm{HCl}$ showing maximum absorbance at $267.2 \mathrm{~nm}$ 


\section{Linearity}

The linearity studies of the drug were performed by plotting different concentrations of standard solution against their respective absorbance as shown in fig. 3 . The drug was found to be linear in the concentration range of $5-30 \mu \mathrm{g} / \mathrm{ml}$.
The correlation co-efficient values were found to be 0.999 , and the calibration curve shows that the drug obeys beer's law limit within the concentration range. Furthermore, the overlay spectra of gem $\mathrm{HCl}$ in working solutions support the linearity results observed in the standard curve as in fig. 4 .

Table 1: Comparison of absorbance of gem $\mathrm{HCl}$ in different solvent

\begin{tabular}{|c|c|c|c|}
\hline Concentration $(\mu \mathrm{g} \backslash \mathrm{ml})$ & PBS pH 7.4* \pm SD & PBS pH 6.8* \pm SD & Distilled water* \pm SD \\
\hline 5 & $0.170 \pm 0.003$ & $0.185 \pm 0.004$ & $0.191 \pm 0.0033$ \\
\hline 10 & $0.310 \pm 0.004$ & $0.342 \pm 0.003$ & $0.356 \pm 0.002$ \\
\hline 15 & $0.465 \pm 0.002$ & $0.476 \pm 0.004$ & $0.493 \pm 0.001$ \\
\hline 20 & $0.618 \pm 0.004$ & $0.638 \pm 0.001$ & $0.640 \pm 0.004$ \\
\hline 25 & $0.760 \pm 0.003$ & $0.774 \pm 0.002$ & $0.777 \pm 0.002$ \\
\hline 30 & $0.944 \pm 0.002$ & $0.946 \pm 0.004$ & $0.941 \pm 0.001$ \\
\hline
\end{tabular}

*Each value is the average of three determinations $(n=3)$

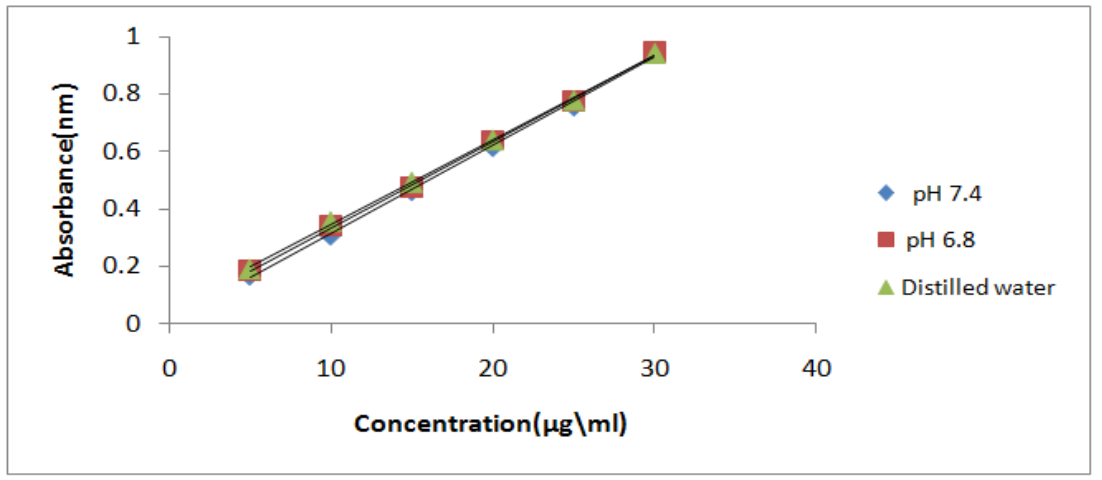

Fig. 3: Calibration plot of gemcitabine $\mathrm{HCl}$

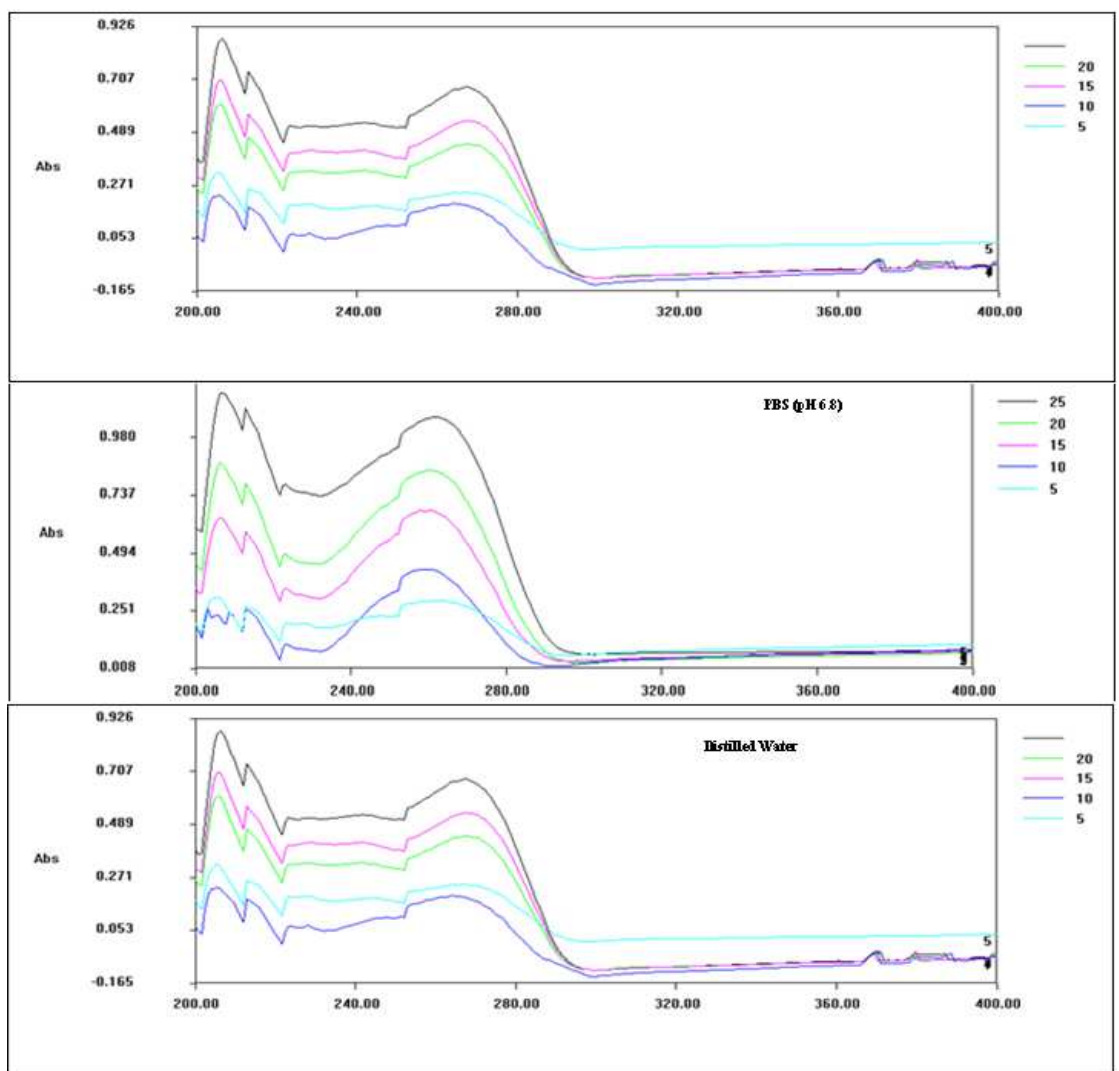

Fig. 4: Overlay spectra of drug in phosphate buffer 7.4, 6.8and distilled water 


\section{Precision (Intraday and Interday Study)}

The Precision was determined as:

\section{Intraday precision}

The intraday precision was determined by analyzing the drug at particular concentration for three times on the same day taking the time intervals of $3 \mathrm{~h}$ at 10:00 AM, 1:00 PM and 4:00 PM respectively.

\section{Interday precision}

The Inter day precision was determined by analyzing the samples daily, for three consecutive days. The values of relative standard deviation (\%RSD) were in the range of $0.089-0.651 \%$ respectively. This indicates the reproducibility of the method. The results are shown in table 2. The precision results indicate that the current method was reliable and repeatable [23]. Thus, the methodology can be applied for the determination of drug in different formulations like targeting of pancreatic as well as for bladder cancer.

Table 2: Inter day and intraday precision data and statistical results

\begin{tabular}{|c|c|c|c|c|c|c|}
\hline Solvent & $\begin{array}{l}\text { Absorbance } \\
\text { (intraday) } \\
(\mu \mathrm{g} / \mathrm{ml})\end{array}$ & $\begin{array}{l}\text { Absorbance } \\
\text { (intraday) } \\
(\mu \mathrm{g} / \mathrm{ml})\end{array}$ & $\begin{array}{l}\text { Intraday } \\
\text { precision } \\
(\% \text { age conc) } \pm S D\end{array}$ & $\begin{array}{l}\text { Interday } \\
\text { precision (\%age conc) } \\
\pm \text { SD }\end{array}$ & $\begin{array}{l}\text { Intraday } \\
\text { precision } \\
(\% \mathrm{RSD})\end{array}$ & $\begin{array}{l}\text { Interday } \\
\text { precision } \\
\text { (\%RSD) }\end{array}$ \\
\hline $\mathrm{pH} 7.4$ & 0.60 & 0.61 & $98 \pm 0.005$ & $97 \pm 0.003$ & 0.406 & 0.522 \\
\hline $\mathrm{pH} 6.8$ & 0.63 & 0.62 & $99.9 \pm 0.004$ & $98.4 \pm 0.005$ & 0.181 & 0.651 \\
\hline $\begin{array}{l}\text { Distilled } \\
\text { Water }\end{array}$ & 0.64 & 0.634 & $98.3 \pm 0.001$ & $99.3 \pm 0.002$ & 0.180 & 0.089 \\
\hline
\end{tabular}

$*_{\text {is }}$ the mean of three values $(n=3)$

\section{Accuracy}

To ensure the accuracy, recovery studies were performed by standard addition method at 75\%, 100\% and $125 \%$ levels of drug concentration, to the pre-analyzed samples and percent recovery values were calculated. Recovery experiment indicated the absence of interferences from the commonly encountered pharmaceutical additives and excipients and values of mean recovery were in the range of $99.32-100.33 \%$. The results for the recovery studies were found in the desired limits as shown in table 3.

Table 3: Results of recovery studies at three levels and statistical analysis

\begin{tabular}{llll}
\hline Solvent & Accuracy $(\% \text { recovery })^{*}$ & & \\
\cline { 2 - 4 } & $\mathbf{7 5 \%}(\mathbf{1 0}+\mathbf{5} \boldsymbol{\mu g} / \mathbf{m l}) \pm$ SD & $\mathbf{1 0 0 \%}(\mathbf{1 0 + 1 0} \boldsymbol{\mu g} / \mathbf{m l}) \pm$ SD & $\mathbf{1 2 5 \%}(\mathbf{1 0 + 1 5} \boldsymbol{\mu g} / \mathbf{m l}) \pm$ SD \\
\hline pH 7.4 & $99.32 \pm 0.09$ & $100.33 \pm 0.48$ & $100.69 \pm 0.81$ \\
pH 6.8 & $99.66 \pm 0.1$ & $100.66 \pm 0.32$ & $100.69 \pm 0.76$ \\
Distilled Water & $99.77 \pm 0.12$ & $100.11 \pm 0.23$ & $100.33 \pm 0.98$ \\
\hline
\end{tabular}

*Each value is the average of three determinations $(n=3)$

\section{Repeatability}

The repeatability of the instrument was validated by taking the absorbance of six samples of the same concentration $(20 \mu \mathrm{g} / \mathrm{ml})$ in different working solvents.
The SD and \%R. SD were in the given limits as shown in table 4 . The repeatability of methodology is very important for routine result analysis of drug in bulk as well as in formulations. Moreover, the current results proved that there was no significant change in results on repetition of methodology [24].

Table 4: Results of repeatability studies in different working solvents

\begin{tabular}{llll}
\hline Concentration $(\boldsymbol{\mu g} \backslash \mathbf{m l})$ & Absorbance(pH 7.4)* & Absorbance(pH 6.8)* $^{*}$ & Absorbance (distilled water) $^{*}$ \\
\hline 20 & 0.616 & 0.639 & 0.638 \\
20 & 0.618 & 0.638 & 0.638 \\
20 & 0.617 & 0.638 & 0.638 \\
20 & 0.618 & 0.637 & 0.631 \\
20 & 0.618 & 0.637 & 0.638 \\
20 & 0.619 & 0.634 & 0.638 \\
Mean & $0.617 \pm 0.0013$ & $0.637 \pm 0.00172$ & $0.636 \pm 0.00285$ \\
SD & 0.00103 & 0.00172 & 0.00285 \\
\%RSD & 0.16 & 0.27 & 0.44 \\
\hline
\end{tabular}

$*_{\text {is }}$ the mean of three values $(n=3)$

\section{Robustness study}

Robustness studies assumed that the small variations in any of the variables did not significantly affect the results (table 5). The robustness study provided the liability of the proposed method during routine analysis and proved that change in instrument, show no significant effect on results.

\section{Ruggedness study}

Ruggedness of the method was determined by carrying out the analysis by different analyst and the respective absorbance of $20 \mu \mathrm{g} / \mathrm{ml}$ was noted. The result was indicated as \%RSD, which should be less than 2 as shown in table 6 . The ruggedness analysis, indicates that there was no significant change in reliability and repeatability of methodology with the change of analyst [23].

\section{Assay of polymeric nanoparticles (PNP's)}

The optimized spectrophotometric method was applied to the direct determination of gem $\mathrm{HCl}$ in polymeric nanoparticles without any sample extraction or filtration. From the absorbance value, the drug content was calculated. Furthermore, the results obtained from assay of polymeric nanoparticles showed that the current method was validated because drug content recovered was $97.97 \%$ with $\%$ RSD 0.44 as shown in table 7 . 
Table 5: Results of robustness studies and statistical analysis

\begin{tabular}{|c|c|c|c|c|c|c|}
\hline \multirow{2}{*}{$\begin{array}{l}\text { Concentration } \\
(\mu \mathrm{g} \backslash \mathrm{ml})\end{array}$} & \multicolumn{2}{|c|}{ Absorbance(pH 7.4)* } & \multicolumn{2}{|c|}{ Absorbance(pH 6.8)* } & \multicolumn{2}{|c|}{ Absorbance(distilled water) ${ }^{*}$} \\
\hline & 665.9 & 669.2 & 665.9 & 669.2 & 665.9 & 669.2 \\
\hline 20 & 0.618 & 0.570 & 0.635 & 0.581 & 0.638 & 0.569 \\
\hline 20 & 0.618 & 0.571 & 0.631 & 0.581 & 0.631 & 0.568 \\
\hline 20 & 0.618 & 0.571 & 0.633 & 0.581 & 0.639 & 0.568 \\
\hline 20 & 0.619 & 0.571 & 0.634 & 0.581 & 0.638 & 0.568 \\
\hline 20 & 0.619 & 0.571 & 0.638 & 0.581 & 0.638 & 0.568 \\
\hline 20 & 0.617 & 0.571 & 0.638 & 0.580 & 0.638 & 0.568 \\
\hline Mean & 0.618 & 0.571 & 0.634 & 0.581 & 0.637 & 0.568 \\
\hline SD & 0.000735 & 0.00040 & 0.00278 & 0.000408 & 0.00296 & 0.0142 \\
\hline$\%$ RSD & 0.12 & 0.071 & 0.43 & 0.071 & 0.46 & 0.071 \\
\hline
\end{tabular}

*is the mean of three values $(n=3)$

Table 6: Results of ruggedness studies (by two analysts) in different working solvents

\begin{tabular}{llllll}
\hline $\begin{array}{l}\text { Concentration } \\
(\boldsymbol{\mu g} \backslash \mathbf{m l})\end{array}$ & \multicolumn{2}{l}{ Absorbance(pH 7.4)* } & \multicolumn{2}{l}{ Absorbance(pH 6.8)* } & \multicolumn{2}{c}{ Absorbance(distilled water)* } \\
\cline { 2 - 6 } & Analyst I & Analyst II & Analyst I & Analyst II & Analyst I \\
\hline 20 & 0.619 & 0.617 & 0.637 & 0.636 & 0.63 \\
20 & 0.619 & 0.619 & 0.637 & 0.637 & 0.63 \\
20 & 0.618 & 0.618 & 0.637 & 0.635 & 0.63 \\
20 & 0.618 & 0.619 & 0.637 & 0.637 & 0.63 \\
20 & 0.618 & 0.618 & 0.636 & 0.636 & 0.635 \\
20 & 0.618 & 0.618 & 0.637 & 0.637 & 0.632 \\
Mean & 0.618 & 0.618 & 0.637 & 0.636 & 0.633 \\
SD & 0.00051 & 0.0011 & 0.013 & 0.0008 & 0.633 \\
\%RSD & 0.083 & 0.189 & 0.064 & 0.12 & 0.002 \\
\hline
\end{tabular}

$*_{\text {is }}$ the mean of three values $(\mathrm{n}=3)$

Table 7: Results of the assay of pharmaceutical formulation

\begin{tabular}{|c|c|c|c|c|}
\hline \multirow[t]{2}{*}{ Formulation } & \multirow[t]{2}{*}{ Amount taken* $(\mu \mathrm{g} / \mathrm{ml})$} & \multicolumn{3}{|l|}{ UV spectrophotometric method } \\
\hline & & Amount recovered $(\mu \mathrm{g} / \mathrm{ml}) * \pm \mathrm{SD}$ & \% Drug recovered* \pm SD & \% RSD* \\
\hline PNP's & 10 & $9.797 \pm 0.09$ & $97.97 \pm 0.9$ & 0.44 \\
\hline
\end{tabular}

*is the mean of three values $(n=3)$.

Table 8: Summary of all the validation parameters

\begin{tabular}{llll}
\hline Validation parameter & Phosphate buffer (pH 7.4) & Phosphate buffer (pH 6.8) & Distilled water \\
\hline Absorption maxima $\left(\lambda_{\max }\right)$ & $267.2 \mathrm{~nm}$ & $267.2 \mathrm{~nm}$ & $267.2 \mathrm{~nm}$ \\
Linearity Range & $5-30 \mu \mathrm{g} / \mathrm{ml}$ & $5-30 \mu \mathrm{g} / \mathrm{ml}$ & $5-30 \mu \mathrm{g} / \mathrm{ml}$ \\
Standard Regression Equation & $\mathrm{y}=0.0307 \mathrm{x}+0.0074$ & $\mathrm{y}=0.0301 \mathrm{x}+0.0346$ & $\mathrm{y}=0.0295 \mathrm{x}+0.0304$ \\
Intercept & 0.0074 & 0.0346 & 0.0304 \\
Slope (m) & 0.0307 & 0.0301 & 0.0295 \\
Correlation Co-efficient $\left(\mathrm{R}^{2}\right)$ & 0.998 & 0.999 & 0.999 \\
\% RSD for Intra-day (n=3) Precision & 0.406 & 0.181 & 0.180 \\
\% RSD for Inter-day (n=3) Precision & 0.522 & 0.651 & 0.089 \\
Repeatability (\% RSD) & 0.167 & 0.270 & 0.448 \\
LOD & 0.268 & 0.532 & 0.197 \\
LOQ & 0.815 & 1.61 & 0.679 \\
\hline
\end{tabular}

\section{CONCLUSION}

A simple, accurate, precise, robust and rapid UV visible spectrophotometric method has been developed for estimation of gem $\mathrm{HCl}$ from its pharmaceutical formulation. Thus it can be extended for routine analysis of gem $\mathrm{HCl}$ in pharmaceutical industries and hospitals and research laboratories. Unlike the LC/MS procedure and HPLC procedures, the UV-visible spectrophotometer instrument is simple and not of highly expensive on the other hand in simplicity and user friendly the method could be considered superior in comparison with the previously reported methods. The current method has wide range of accuracy, precision, repeatability, robustness and ruggedness.

\section{CONFLICT OF INTERESTS}

The authors declare that they do not have any financial and personal relationships with other people or any other organizations that could inappropriately influence this research work.

\section{ACKNOWLEDGMENT}

The authors are grateful to Dr. Chander Mohan, Director-Principal and all staff members of Rayat-Bahra Institute of Pharmacy, Hoshiarpur, Punjab for the providing us the facilities for carrying out this research work. The authors would also thankful to Neon laboratories, Mumbai for providing the gift sample of gemcitabine hydrochloride.

\section{CONFLICT OF INTERESTS}

Declare none

\section{REFERENCES}

1. Reddy LH, Couvreur P. Novel approaches to deliver gemcitabine to cancers. Curr Pharm Design 2008;14:1124-37.

2. Berlin J, Benson AB. Gemcitabine remains the standard of care for pancreatic cancer. Nat Rev: Clin Oncol 2010;7:136-7. 
3. Khaira R, Sharma J, Saini V. Development and characterization of nanoparticles for the delivery of gemcitabine hydrochloride. Hindawi Publishing Corporation Sci World J 2014;4:43-7.

4. Singh R, Shakya AK, Naik R, Shalan N. Stability-indicating HPLC determination of gemcitabine in pharmaceutical formulations. Int J Anal Chem 2015;12:45-56.

5. Mini E, Nobilli S, Caciagli C, Landini I. Cellular pharmacology of gemcitabine. Ann Oncol 2006;5:7-12.

6. Mangamma K, Rao DV, Mohan VS, Prasanna AD. Method development and validation of gemcitabine and irinotecan by RPHPLC in pharmaceutical formulation. Int J Chem Anal Sci 2012;3:1500-2.

7. Singh R, Shakya AK, Naik R, Shalan N. Stability-indicating HPLC determination of gemcitabine in pharmaceutical formulations. Int J Anal Chem 2015;5:56-67.

8. Krishna RM, Ramesh M, Buela M, Kumar TS. Method development and validation for the assay of gemcitabine hydrochloride in pharmaceutical dosage forms by RP-HPLC. Indo Am J Pharm Res 2011;1:189-95.

9. Reddy MS, Firadous S. Spectrophotometric estimation of gemcitabine $\mathrm{HCl}$ in pharmaceutical dosage form via oxidative coupling reaction. Chem Sci Transactions 2015;4:1102-6.

10. Wang LZ, Yong WP, Soo RA, Lee SC, Soong R, Lee HS, et al. Rapid determination of gemcitabine and its metabolite in human plasma by LC-MS/MS through micro protein precipitation with minimum matrix effect. J Pharm Sci Res 2009;1:23-32.

11. Annapurna MM, Kumar BSP, Venkatesh B. Validated stability indicating liquid chromatographic method for the determination of gemcitabine hydrochloride in parenterals. Indo Am J Pharm Res 2013;3:23-36.

12. Wanga G, Jhao G, Chen H, Ding D, Kou L, Kan L, et al. Development and validation of a UPLC-MS/MS assay for the determination of gemcitabine and its L-carnitine ester derivative in rat plasma and its application in oral pharmacokinetics. Asian J Pharm Sci 2017;16:301-4.

13. Indian Pharmacopoeia. Buffer Solutions 2007;1:240-2

14. Kumar BK, Rajan VST, Begum NT. Analytical method development and validation of lidocaine in ointment formulation by UV spectrophotometric method. Int J Pharm Pharm Sci 2012;4:67-74.

15. Tarkase KN, Admane SS, Sonkhede NG, Shejwal SR. Development and validation of UV-spectrophotometric methods for determination of moxifloxacin $\mathrm{HCl}$ in bulk and pharmaceutical formulations. Scholars Res Library Pharm Chem 2012;4:1180-5.
16. Jain PS, Chaudhari AJ, Patel SA, Patel ZN, Patel DT. Development and validation of the UV spectrophotometric method for determination of terbinafine hydrochloride in bulk and in formulation. Pharm Methods 2011;2:89-95.

17. Sethuraman S, Radhakrishnan K, Solomonon A. Analytical method development and validation of caffeine in tablet dosage form by using UV-spectroscopy. Int J Novel Trends Pharm Sci 2011:3:90-9.

18. Balasaheb BG, Balasaheb AK, Subhash TR, Jijabapu K, Sudhakar PS. Development and validation of UV-spectrophotometric method for estimation of dolute gravirsodium in tablet dosage form. Malaysian J Anal Sci 2015;19:67-78.

19. Pankti D, Kusum M, Mehul P. Development and validation of UV-visible spectrophotometric method for simultaneous estimation of momentasone furoate, hydroquinone and tretinoin from their pharmaceutical dosage form. Int J Pharm Sci 2013;49:296-300.

20. Dhartarkar PG, Kalamkar RV, Saoji SD, Ingle SG, Atram SC, Game MD. Development and validation of UV spectrophotometric method for estimation of dexibuprofen in bulk and dosage form. Scholars Res Library Pharm Chem 2011;3:361-6.

21. Kamboj A, Sidana A, Jain UA. Development and validation of UV spectroscopic methods for simultaneous estimation of salbutamol sulphate and doxophylline in combined solid dosage form. Int J Pharm Pharm Sci 2017;9:117-22.

22. Acharjya SK, Mallick P, Panda P, Kumar KR, Annapurna MM. Spectrophotometric methods for the determination of Letrozole in bulk and pharmaceutical dosage form. J Adv Pharm Technol Res 2010;1:360-70.

23. Boulanger B, Dewe W, Chiap P, Crommen J, Hubert PH. An analysis of the SFSTP guide on validation of bioanalytical methods: progress and limitations. J Pharm Biomed Anal 2003;32:753-65.

24. Pourmand M, Azar R, Aghavalijamaat M. Development of validated UV spectrophotometric method for in vitro analysis of sumatriptan in pharmaceutical preparations in comparison with HPLC. Pharm Chem J 2011;44:585-9.

\section{How to cite this article}

- Taranjit Kaur, Sukhjinder Kaur, Parminderjit Kaur. Development and validation of UV-spectrophotometric methods for determination of gemcitabine hydrochloride in bulk and polymeric nanoparticles. Int J Appl Pharm 2017;9(5):60-65. 